\title{
Antioksidanter ved akutt hjerneskade?
}

\author{
Kan forskning om hjerneskader \\ hos mus gi muligheter for bedre \\ behandling av hodeskader hos \\ mennesker?
}

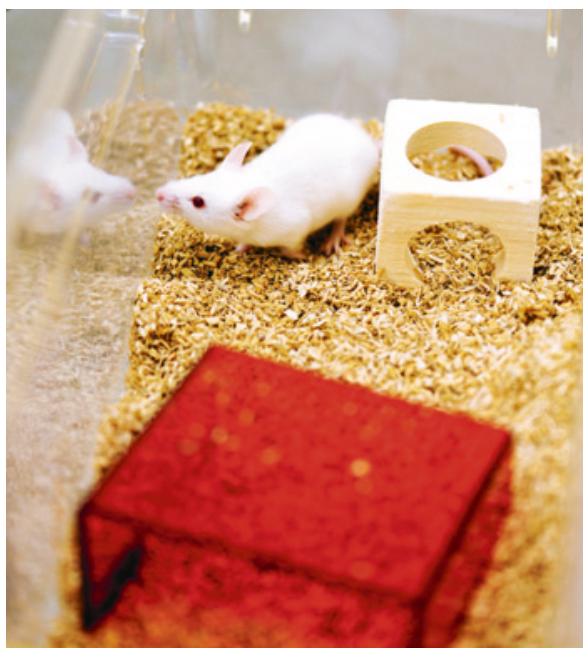

Illustrasjonsfoto: Sciencephoto/NTB scanpix
Hodetraumer kan skade hjernefunksjonen, men man vet lite om hvordan dette skjer. En ny musemodell er nylig etablert for å simulere moderate hodeskader hos mennesker (1).

Tykkelsen på musenes hodeskalle ble redusert fra omtrent $100 \mu \mathrm{m}$ til $30 \mu \mathrm{m}$. Da kunne man med tofotonmikroskopi registrere hjerneskaden som oppsto når skalletaket forsiktig ble trykt innover. Makrofager i meningene forsvant raskt, meningene ble inflammerte, og diffusjonsbarrieren som dannes av astrocytter, mellom meninger og nervevev, ble permeabel. Hullene i barrieren ble delvis tettet av mikroglia. Etter 9-12 timer kunne man se nervecelledød.

Forbehandling med glutation, som motvirker reaktive oksygenderivater, reduserte reaksjonen i meningene og nervecelleskaden, men gitt $0-3$ timer etter traumet var det bare nervecelleskaden som ble dempet. Adenosintrifosfat frigjort fra skadede celler stimulerer purinreseptorer. Hemming av slike reseptorer forverret nervecelleskaden. Studien viser at hemming av reaktive oksygenderivater og stimulering av visse purin- reseptorer er gunstig for å hemme hjerneskade hos mus. Hvorvidt denne kunnskapen har overføringsverdi til hodeskader hos menneske, er usikkert.

- Behovet for mer kunnskap om patogenese, sekundærskade og celledød ved lett traumatisk hjerneskade er stort, sier Rolf Hanoa, overlege ved Nevrokirurgisk avdeling, Oslo universitetssykehus, Ullevål. - Denne studien viser at traumeinduserte patologiske forandringer i musehjernen dempes av transkranial injeksjon av en antioksidant. Det er imidlertid langt fra musepatofysiologi til human nevropatofysiologi. Forfatterne av denne studien har etablert en studiemodell som gir mer forståelse, men som også reiser nye spørsmål, sier Hanoa.

\section{Haakon B. Benestad}

Universitetet i Oslo

\section{Litteratur}

1. Roth TL, Nayak D, Atanasijevic T et al. Transcranial amelioration of inflammation and cell death after brain injury. Nature 2014; 505: 223-8.

\section{Forurensning gir økt risiko for akutt hjertesykdom}

\section{Selv ved eksponering som er under etablerte grenseverdier, gir lang- varig utendørs partikkelforurensning økt risiko for akutt koronarsykdom.}

Sammenhengen mellom langvarig eksponering for luftforurensning og akutt kardiovaskulær sykdom er usikker. Effekten av luftforurensning på akutt hjerteinfarkt og ustabil angina pectoris er nå undersøkt i en europeisk multisenterstudie (1).

11 kohorter, som omfattet rundt 100000 personer i Finland, Sverige, Danmark, Tyskland og Italia, ble fulgt i gjennomsnittlig 11,5 år. En økning på $5 \mu \mathrm{g} / \mathrm{m}^{3}$ i estimert årlig konsentrasjon av partikler $<2,5 \mu \mathrm{m}$ i diameter $\left(\mathrm{PM}_{2,5}\right)$ var assosiert med $13 \%$ økt risiko for akutte koronare hendelser (hasardratio 1,$13 ; 95 \% \mathrm{KI} 0,98-1,30)$, mens $10 \mu \mathrm{g} / \mathrm{m}^{3}$ økning i $\mathrm{PM}_{10}$ var forbundet med $12 \%$ økt risiko (hasardratio 1,$12 ; 95 \% \mathrm{KI}$ 1,01-1,25). Signifikante positive assosiasjoner ble også funnet ved lavere nivåer enn de europeiske grenseverdiene på $25 \mu \mathrm{g} / \mathrm{m}^{3}$ for $\mathrm{PM}_{2,5}$ og $40 \mu \mathrm{g} / \mathrm{m}^{3}$ for $\mathrm{PM}_{10}$ som årsgjennomsnitt.

- Luftforurensningen i denne studien svarer til nivåene i de største norske byene for flere av kohortene, sier seniorforsker Marit
Låg og forsker Bente Oftedal ved Divisjon for miljømedisin, Folkehelseinstituttet.

- En usikkerhet ved denne type studier er klassifisering av helseutfallene. Spesielt når det gjelder dødsfall utenfor sykehus kan det være vanskelig å fastslå riktig dødsårsak. En annen usikkerhet gjelder beregningen av luftforurensningseksponeringen. I denne studien er eksponeringen også beregnet for en periode etter forekomsten av helseutfallene. Dessuten er ikke vedfyring fanget opp i modellen, påpeker Oftedal.

- Til tross for visse svakheter er dette en viktig studie som støtter opp under det syn at dagens grenseverdier for partikkelforurensning i EU og Norge er for høye, sier Låg.

\section{Trine B. Haugen}

Tidsskriftet

\section{Litteratur}

1. Cesaroni G, Forastiere F, Stafoggia M et al. Long term exposure to ambient air pollution and incidence of acute coronary events: prospective cohor study and meta-analysis in 11 European cohorts from the ESCAPE Project. BMJ 2014; 348: f7412.

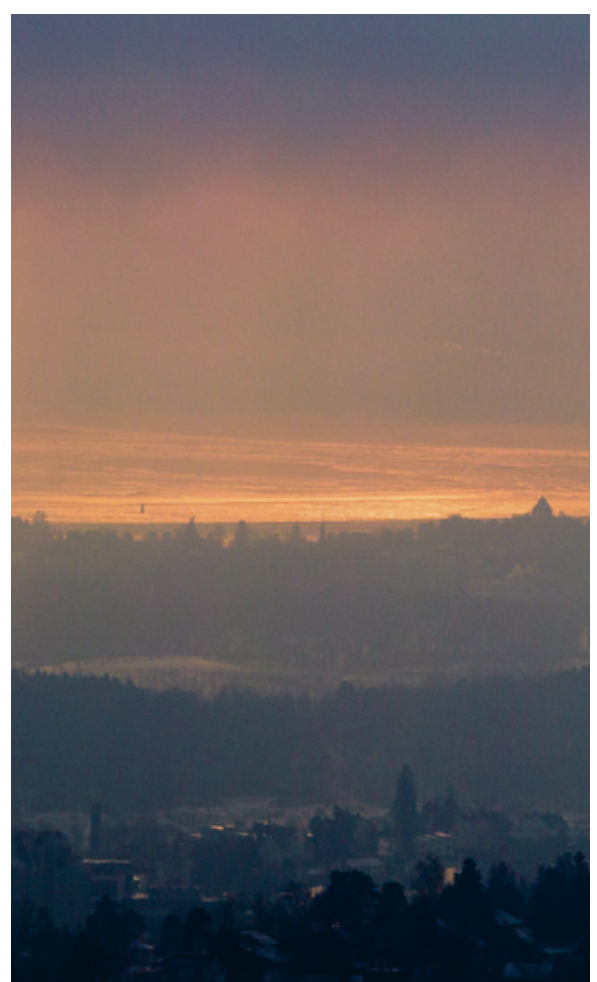

Illustrasjonsfoto: NTB scanpix 